\title{
The usefulness of parody
}

\section{A timely rescue from a 'too clever' idea.}

$\mathrm{C}$ lar biologists, and it quickly casts a spell on the temporary visitors teaching or attending the courses it runs each summer. For the permanent staff, all of whom could in those early days live on its idyllic Long Island campus, the effects are more complicated, simply because it is such a hard place to leave. My first impressions, as a temporary visitor, were negative. True, there was the luxury of being able to set up experiments while still in my pyjamas, return to our nearby apartment to read The New York Times in slippered ease, and then finally go back to the lab to harvest the yield from my now-ripe cultures. But this life seemed too pampered. Indeed, some years later my technician Paula de Lucia, after whom the gene polA was named, summed it up to some newspaper reporters in the scornful sentence, "The staff here do not even have to go shopping!"

In 1960, my family had come to Cold Spring Harbor so that I could spend a sabbatical year in Al Hershey's lab. He was the experimentalist who, more than any other and by his own solitary efforts, had generated the science of molecular biology. An austere figure, he made it his custom to work two days in every one - breakfast/work/dinner/sleep, and then a second round of the same starting late in the afternoon. He was a singularly silent man, and just about the only time you could get him to talk was when he was standing by the sink washing up glassware - apparently a task that he found was the only way to escape from the ceaseless burden of thought.

Faced with such a paragon, I felt I had to do something spectacular. Those were early days in the coming together of genetics and biochemistry. You could study either the genetics or the biochemistry of bacterial viruses, but only in a rather restricted sense could you directly link the behaviour of their genes to the behaviour of their DNA. I resolved to find a more direct way. Pleased with myself for having worked out a feasible (albeit complicated) method, I was explaining the whole thing to Bob Edgar, whom I happened to meet one evening as he was on his way to the weekly square dance that was held on one of the laboratory's lawns. Bob was one of Max Delbrück's cohort of young bacteriophage geneticists who was in Cold Spring Harbor to teach the Bacteriophage Course.

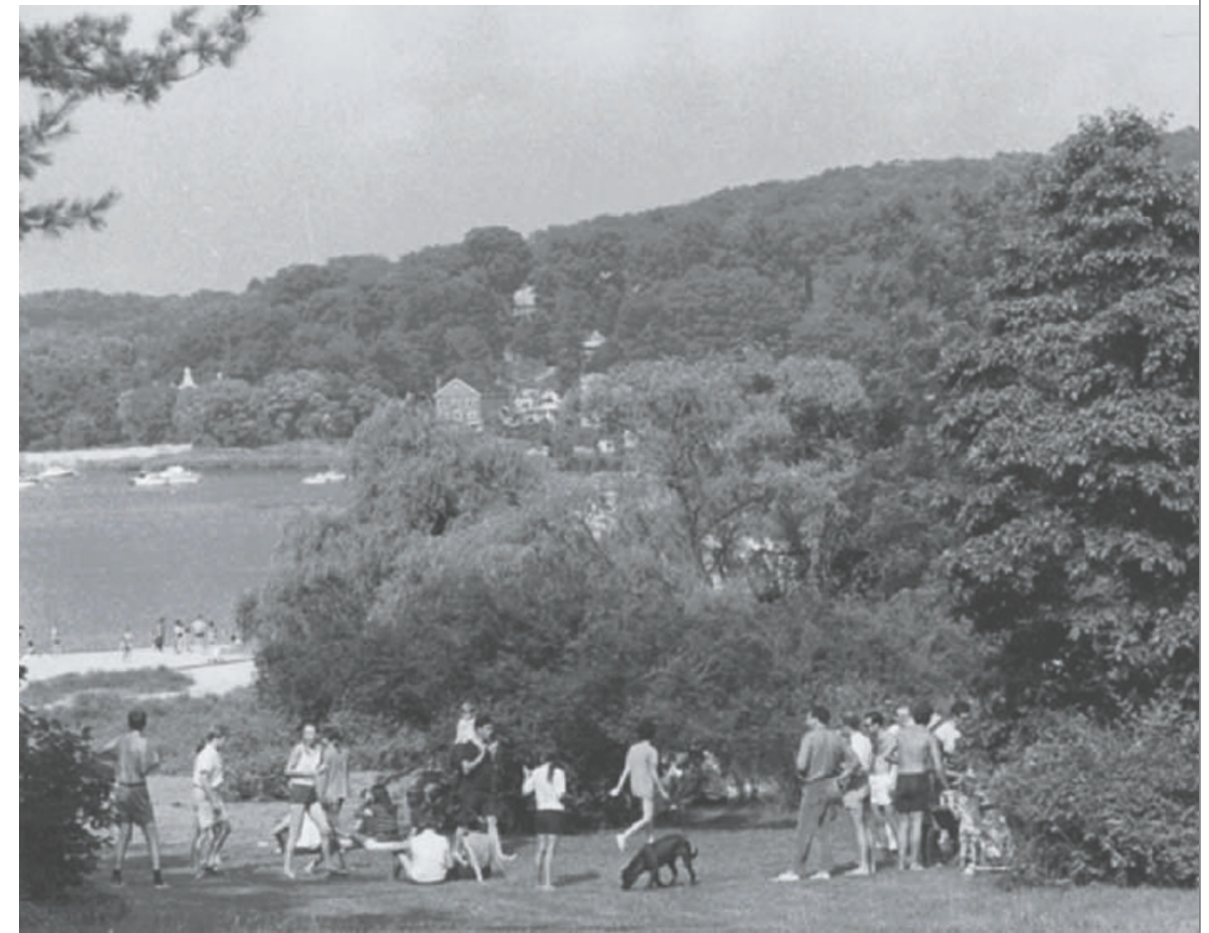

Picture perfect: the relaxed atmosphere of Cold Spring Harbor cuts through hierarchies.

Almost instantly, I came to regret having been so forthcoming. Edgar proceeded to convert my beautiful design into instructions for an imaginary square dance, prancing from one side of the road to the other as he acted out a dance of bacteriophage particles, each marked with a different isotope, pairing and separating, moving in lines, re-assorting themselves and so on. This lasted for the 300 yards between his classroom and the lawn with its waiting human dancers, where he plunged off into the golden twilight, leaving my experiment in tatters.

After some post-Edgar soul-searching I switched to a more straightforward project. Hershey (and Cyrus Levinthal at Columbia University) had just established that the DNA in each of the bacteriophage particles they were working with consisted of a single giant molecule. But it was not clear whether it was simply a double helix or something more complicated. Although the structure of DNA had been published several years before, the vision still seemed too good to be true. Was genetic information really stored in the linear sequence of the bases of DNA, and could it possibly be replicated in the way that Jim Watson and Francis Crick had suggested? Could the whole of genetics rest on something so simple? I had recently used tritium labelling as a way to localize the sites for the replication of vaccinia virus DNA in mammalian cells. I resolved to use the same technique to measure the length of bacteriophage DNA, and thereby determine if it had the right length for a double helix or was shorter and therefore had a more complicated structure.

Thanks to Edgar's intervention, everything worked out well and the project nicely lasted out our year in Long Island. In the nick of time, he had made me see that the virtue of my initial project lay solely in its complexity, not in what it would actually tell anyone. Some years later, the pianist Glenn Gould delivered the same message at the end of his Fugue for Four Voices and Strings with the words "Never be clever for the sake of being clever!".

More importantly for my later stint as director of Cold Spring Harbor, Edgar's intervention made me see that one of the virtues of the lab - as someone once pointed out - was that its social structure is not 'vertically stratified'. I am not sure of the origin of this estimable trait, but I suspect it came from Max Delbrück. To give an example of his irreverence, I remember his saying how he was surprised to see the list of the new Nobel prizewinners and to realize that a whole year had passed since he had got his. "And I hadn't heard of any of them!" he added.

John Cairns is at the Clinical Trial Service Unit, Radcliffe Infirmary, Oxford OX2 6HE, UK. 